\title{
MAJOR CHANGES OF TRENDS IN ELT
}

\section{Mr. Hitendra H Vyas}

The perspectives on major trends in the global ELT field has been a significant issue nowadays. The trends in today's ELT field can be broken down into three major categories: globalization, localization, and interdisciplinary collaboration.

\section{Trend 1: Changing perspectives on English teaching and learning}

Over the last 50 years, and especially during the last 20 years, the ELT field has seen a dramatic change in our views of the role of English language teaching. English educators have realized that many language learners know more than two languages. English is not simply their second language anymore. With this awareness, acronyms for the field have also evolved-from TESL (teaching English to second language learners) to TESOL (teaching English to speakers of other languages), from Western English to English as an international language (EIL). The term TENOR (teaching English for no obvious reasons) has been replaced by TESR (teaching English for social responsibilities) and CLT2 (communicative language teaching, contextualized language teaching). Nowadays, more and more research and discussions have focused on the issues of "World Englishes" and English as a lingua franca (ELF) rather than simply referring to any English spoken outside of the United States, Canada, the United Kingdom, and Australia as EFL. 


\section{Trend 2: Changes in goals of English teaching and learning}

The goals of ELT have changed from focusing solely on developing language skills and mimicking native English speakers to fostering a sense of social responsibility in students. More and more educators realize that we can't claim success in teaching, no matter how fluent our students become, if they are ignorant of world issues, have no social conscience, or use their communication skills for international crime, corruption, or environmental destruction (Cates, 1997; Brown, 1994). With this growing awareness of the importance of producing responsible citizens for society, teachers now well recognize that the teaching of English is not simply a project to prepare students to imitate native English speakers as language learners but that it should produce fully competent language users, critical thinkers, and constructive social change agents, as Crystal (2004) and Cook (2005) noted.

\section{Trend 3: Changes in approaches to teaching}

The 21st century is referred as the "Post methods Era" by many scholars (Kumaravadivelu, Brown, Larsen-Freeman, and Mellow to name a few), where the focus of teaching is on eclecticism. Eclecticism involves the use of a variety of language learning activities, each of which may have very different characteristics and may be motivated by different underlying assumptions. Today, the use of L1 in L2 pedagogy and the use of different accents in listening activities and tests are encouraged in teaching and learning.

\section{Trend 4: Changes in teaching content, curriculum design, and assessment}

The field is recognizing the growing importance of content and disciplinary knowledge.

This increased focus on CBLI, CLIL, SIOP, and ESP has meant that more and more programs require English teachers to use cross-curricular, cross-disciplinary content in teaching and to 
teach both the content and English. Textbooks and learning materials include more multicultural content, drawing on both local and global resources to help students gain multiple perspectives and cultural understandings. Curriculum design is more content based and theme based with emphases on both language and content knowledge. Learning outcomes and learning standards are broader and pursue the development of not only language skills, but critical thinking, learning strategies, and related content knowledge and skills in the real world. Today, standards, accountability, and assessment have become a major focus of the educational reform in many countries in the world.

\section{Trend 5: Expanding the dimension of communicative competence}

A large focus of recent research and publications has been expansion of the framework of communicative competence. Some scholars have introduced a new way of looking at second language acquisition (SLA) as "multi-competence" (Cook, 2012), and others (Byram, 1997, Kohn, 2013) focus on the importance of intercultural communicative competence. The implication here is that when teaching intercultural communicative competence, teachers need to attend to both local and international cultures. The goal is to produce effective language users competent to use English as an international language, not just learners "inner- circle" countries" languages and cultures.

\section{Trend 6: Changing views of an effective English educator}

With the changing views of communicative competence and the awareness of intercultural competence, perceptions of what constitutes an effective English teacher are also changing. Recent studies on World Englishes and ELF, as well as the roles of nonnativeEnglish-speaking teachers (NNESTs) in the TESOL field, have made more people recognize that the effectiveness of English teachers should be determined by their linguistic, instructional, and 
Towards Excellence: An Indexed, Refereed \& Peer Reviewed Journal of Higher Education / Mr. Hitendra Vyas / Page 26- 31

intercultural competence rather than simply by their linguistic identity. We want to make sure that our students are served by well-prepared and well qualified teachers regardless their first language background.

\section{Trend 7: Rapid development and integration of information technology in ELT}

The recent rapid development of technology and the use of cell phones and different multimedia devices have opened endless possibilities for teachers to teach English and access information. The Internet, YouTube, Web.2.0, e-books, and various websites have changed how we prepare our lessons and instruct our students. Now, with ready-made materials at the touch of a keyboard button, it is a lot easier to bring real-life issues to the classroom and have a meaningful discussion. Appropriate integration of technology in the classroom encourages students to use language in many different ways. Furthermore, learners from different parts of the world can get connected and exchange ideas via the Internet and other media devices. Students may know more than their teachers about how to use technology, and yet they need proper guidance from the teachers on how to select, analyze, and utilize the right information to achieve their learning goals.

\section{Trend 8: Changing roles and increasing responsibilities of teachers}

With all these new trends, the role of today's teacher is also evolving, and our responsibilities have been increasing. In the 21 st-century classroom, teachers have multiple roles and responsibilities as facilitators of student learning and creators of a productive classroom environment in which students can develop the skills they will need for the 21 st-century workforce. More and more teachers are asked to use collaborative, content-based, project-based curriculum to help students develop higher-order thinking skills, effective communication skills, 
and knowledge of technology. Another change noticed is that many teachers no longer teach in isolation. Teachers have the opportunities to co teach, team-teach, and collaborate with other teachers from other disciplines. It's more important than ever that teachers receive real institutional support including funding and release time to attend professional development activities and implement new ways of teaching and assessing learning. These are essential if we are to prepare our students to be effective users of English and responsible global citizens, and also prepare ourselves to be reflective practitioners and critical social agents in this world of globalized Englishes.

\section{Conclusion}

Thus, the changes of trends in today's ELT field has truly brought a dramatic result nowadays. The goals of ELT have changed from focusing solely on developing language skills and mimicking native English speakers to fostering a sense of social responsibility in students. The field is recognizing the growing importance of content and disciplinary knowledge. A large focus of recent research and publications has been expansion of the framework of communicative competence. The recent rapid development of technology and the use of cell phones and different multimedia devices have opened endless possibilities for teachers to teach English and access information. With all these new trends, the role of today's teacher is also evolving, and our responsibilities have been increasing. 


\section{References}

Brown, H. D. (1994, March). On track to century 21. Plenary talk at the 24th Annual Convention of TESOL (Teachers of English to Speakers of Other Languages), San Francisco, USA.

Byram, M. (1997). Teaching and assessing intercultural communicative competence.

Bristol, United Kingdom: Multilingual Matters.

Cates, K. A. (1997). New trends in global issues and English teaching. The Language

Teacher, 21(5). Retrieved from http://jalt- publications.org/old_tlt/files/97/may/cates.html

Cook, V. (2012) Multi-competence. Retrieved from http://homepage. ntlworld. com/

Vivian .c/Writings/Papers/MCentry.htm

Cook, V. (2005). Basing teasing on the L2 user. In E. Llurda (Ed.), Non-native language teachers: Perceptions, challenges and contributions to the profession (pp. 47-61). New York, NY: Springer Science+Business Media.

Crystal, D. (2004, May 20). Creating a world of languages. Introductory speech presented at the 10th Linguapax Congress, Barcelona.

Kohn, K. (2013, March). Intercultural communicative competence: An English as a lingua franca perspective (PowerPoint), presentation at TESOL Arabia conference.

\section{Mr. Hitendra H Vyas, S. V. Arts College, Ahmedabad, Gujarat, India. hitendrahvyas@gmail.com}

